\title{
A CONSTRUÇÃo dA LÓGICA NARRATIVA NO "SEMIMANGÁ" DE MAURÍcio de SOUSA
}

\author{
THE CONSTRUCTION OF THE NARRATIVE \\ LOGIC IN MAURICIO DE SOUSA'S \\ "SEMIMANGA"
}

\section{LA CONSTRUCCIÓN DE LA LÓGICA NARRATIVA EN EL "SEMIMANGÁ" DE MAURÍCIO DE SOUSA}

\footnotetext{
${ }^{1}$ Doutora em Estudos de Linguagem pela Universidade Federal Fluminense (UFF). É professora do Ensino Básico, Técnico e Tecnológico (EBTT) no Colégio Pedro II, ministrando aulas de Língua Portuguesa e Literatura. Além disso, é Professora Supervisora (Orientadora) no Programa de Residência Docente (Especialização Lato Sensu) do CPII.
} 
RESUMO: O presente trabalho pretende analisar como se constrói a lógica narrativa no "semimangá" Turma da Mônica Jovem, obra de Maurício de Sousa, respeitado quadrinista brasileiro, utilizando como corpus de análise uma edição específica da revista, com uma história composta por micronarrativas que se entrelaçam. Como fundamentação teórica, tomou-se por base principal a Teoria Semiolinguística de Análise do Discurso, de Patrick Charaudeau (1992; 2009), com relação ao modo de organização narrativo e à organização da lógica narrativa.

ABSTRACT: This paper analyzes the construction of the narrative logic in the Turma da Mônica Jovem "semimanga", created by Mauricio de Sousa, respected Brazilian cartoonist, using, as corpus of analysis, a specific edition of this comic book, that brings a story composed by micronarratives that are intertwined. The main theoretical basis used was the Semiolinguistics Theory, by Patrick Charaudeau $(1992 ; 2009)$, related to the discourse organization modes, emphasizing the narrative mode and the organization of narrative logic.

RESUMEN: El presente trabajo pretende analizar cómo se construye la lógica narrativa en el "semimangá" Mónica Joven, obra de Maurício de Sousa, renombrado dibujante brasileño, y utiliza como corpus de análisis una edición específica que trae una historia compuesta por micronarrativas que se entrelazan. Como fundamentación teórica, se tomó por base principal la Teoría Semiolinguística de Análisis del Discurso de Patrick Charaudeau (1992; 2009), con relación al modo de organización narrativo y a la organización de la lógica narrativa.

PALAVRAS-CHAVE: Semiolinguística; Modo Narrativo; Lógica Narrativa; Turma da Mônica Jovem.

KEYWORDS: Semiolinguistics; Narrative Mode; Narrative Logic; Monica Teen.

PALABRAS CLAVE: Semiolinguística; Modo Narrativo; Lógica Narrativa; Mónica Joven.

cos

\section{CONSTRUINDO O ROTEIRO}

Charaudeau (2009, p. 77) define "texto" como a "manifestação material (verbal e semiológica: oral/gráfica, gestual, icônica etc.) da encenação de um ato de comunicação, numa situaçáo dada, para servir ao projeto de fala de um determinado locutor". Pode-se observar, então, que tal definição aproxima-se de uma visão ampliada de texto, que considera seus múltiplos sentidos, suas formas e suas condições internas e externas. Conforme postula Bakhtin (1994, p. 330), "se tomarmos o texto no sentido amplo de 
conjunto coerente de signos, então também as ciências da arte (a musicologia, a teoria e a história das artes plásticas) se relacionam com textos (produtos da arte)”.

Will Eisner (2005, p. 5), famoso desenhista norte-americano, define as histórias em quadrinhos como uma "arte sequencial", ou seja, uma "forma artística e literária que lida com a disposição de figuras ou imagens e palavras para narrar uma história ou dramatizar uma ideia”. Como nos quadrinhos palavras e imagens trabalham juntas para transmitir uma informação e contar uma história, a função narrativo-descritiva é exercida não somente pelas palavras, mas também pelas imagens.

De acordo com Goodman (apud SANTAELLA, 2005, p. 293), "as figuras são símbolos convencionais que se relacionam a seus objetos referenciais do mesmo modo que um predicado se relaciona àquilo a que ele se aplica"; assim, tanto o retrato visual quanto a descrição verbal participariam "na formação e caracterização do mundo, relacionando-se mutuamente junto com a percepção e o conhecimento”. Ao explorar a narratividade dos quadrinhos, portanto, tanto os elementos verbais quanto os imagéticos devem ser considerados.

Nessa perspectiva, o presente trabalho pretende analisar como se constrói a lógica narrativa no "semimangá" Turma da Mônica Jovem - TMJ, obra de Maurício de Sousa (2013), respeitado desenhista brasileiro, utilizando como corpus de análise uma edição da revista que se apresenta como um interessante objeto de análise por conter uma história formada por micronarrativas que se cruzam. Como fundamentação teórica desta pesquisa, será tomada por base principal a Teoria Semiolinguística de Análise do Discurso de Patrick Charaudeau (1992; 2009), com relação ao modo de organização narrativo.

\section{OS MODOS DE ORGANIZAÇÃO DO DISCURSO}

Segundo Charaudeau, cada texto tem algo a dizer e é organizado de acordo com uma determinada estrutura. Conforme o autor, os modos de organizaçáa do discurso constituem "os princípios de organização da matéria linguística, princípios que dependem da finalidade comunicativa do sujeito falante: enunciar, contar, descrever, 
argumentar"(CHARAUDEAU, 2009, p. 68), o que se espelha nos quatro modos de organização do discurso postulados pelo teórico, a saber: o enunciativo, o argumentativo, o descritivo e o narrativo.

O Modo Enunciativo refere-se aos protagonistas, seres da fala, internos ao ato de linguagem, e seus comportamentos particulares; esse modo diz respeito à posição do locutor em relação ao interlocutor, em relação a ele mesmo (ao 'dito') e em relação aos outros discursos. O Modo Argumentativo consiste em saber expor e provar causalidades dos acontecimentos, influenciando o interlocutor e, para que essa persuasão ocorra, é necessário que eles compartilhem representaçóes socioculturais. O Modo Descritivo consiste em nomear, localizar/situar e qualificar os seres do mundo com uma maior ou menor subjetividade. O Modo Narrativo, por sua vez, consiste em construir a sucessão das açóes de uma história no tempo com a finalidade de fazer um relato.

Cabe lembrar, no entanto, que, apesar de em determinado gênero discursivo haver predominância de um ou outro modo, um texto é sempre heterogêneo do ponto de vista de sua organização. Portanto, esse dependerá da situação de comunicação na qual e para a qual foi concebido e das diversas ordens de organização do discurso que foram utilizadas para construí-lo.

É preciso também destacar que os quadrinhos, objeto do presente estudo, são típicas narrativas gráficas ${ }^{2}$, pois sua principal finalidade é contar histórias por meio de palavras e imagens. Por esse motivo, o modo narrativo será abordado mais especificamente no tópico a seguir e aprofundado, posteriormente, ao longo da análise de corpus.

\section{O MODO DE ORGANIZAÇÃo NARRATIVO}

Segundo Charaudeau (2009, p. 153), “contar” não é simplesmente descrever uma sequência de fatos ou acontecimentos, como definem os dicionários. No sentido banal do

\footnotetext{
${ }^{2}$ Eisner (2005, p. 10) define "narrativa gráfica" como "uma descrição genérica de qualquer narração que usa imagens para transmitir ideias".
} 
termo, contar é fazer a descrição de uma sequência de ações, mas não consiste necessariamente em fazer uma narrativa.

O autor afirma que, para que haja narrativa, é necessário um "contador" investido de uma intencionalidade, ou seja, de querer transmitir uma certa representação da experiência do mundo a um "destinatário", de uma certa maneira, em um determinado contexto. Contar representa "uma busca constante e infinita"; é uma atividade linguageira cujo desenvolvimento implica uma série de tensóes e contradiçóes (op. cit., p. 153-154).

Nesse sentido, a narrativa é uma totalidade e corresponde à finalidade do "que é contar" (descreve, ao mesmo tempo, ações e qualificações); o narrativo (modo de organização) é apenas um de seus componentes, assim como o descritivo (op. cit., p. 156).

De acordo com a teoria Semiolinguística, o modo de organização narrativo caracteriza-se por uma dupla articulação: a realização de uma representação narrativa, isto é, daquilo que faz com que essa história torne-se um universo narrado (a organização da encenação narrativa), e a construção de uma sucessão de ações segundo uma lógica que vai constituir a trama da história (a organização da lógica narrativa).

A encenação narrativa "constrói o universo narrado (ou contado) sob a responsabilidade de um sujeito narrante que se acha ligado por um contrato de comunicação ao destinatário da narrativa”. (CHARAUDEAU, 2009, p. 158). Ao falar sobre esse aspecto, Charaudeau (op. cit., p. 183) explica que "quem conta (uma história) não é quem escreve (um livro) nem quem é (na vida)". Nesse sentido, não se deve confundir o indivíduo, ser psicológico e social, o autor, ser que escreveu, e o narrador, "ser de papel”, que conta uma história. Da mesma maneira são diferentes o leitor real, a quem é demandado um mínimo de competência de leitura e o leitor, "ser de papel”, destinatário de uma história contada por um narrador (op. cit., 183-184).

Já a organização da lógica narrativa está voltada para o mundo referencial e é resultado da projeção sobre um plano (a história) de algumas das constantes da manifestação semântica da narrativa, ou seja, é uma hipótese de construção do que constitui a trama de uma história. Esse aspecto, foco do presente trabalho, será detalhado a seguir. 


\section{A ORGANizAÇÃo da lógICA NARRATIVA}

A construção da lógica narrativa realiza-se com a ajuda de alguns componentes, cuja configuração é assegurada por certos procedimentos.

Os componentes da lógica narrativa são de três tipos: os actantes, os processos e as sequências. Os actantes desempenham papéis relacionados à ação da qual dependem; os processos unem os actantes entre si, dando uma orientação funcional à sua ação; as sequências integram processos e actantes numa finalidade narrativa segundo certos princípios de organização. (CHARAUDEAU, 2009, p. 160).

O actante participa na esfera da ação e, para conhecer seu papel narrativo (categoria de discurso), é necessário conhecer o contexto que dá ao enunciado (categoria de língua) sua finalidade narrativa. Esse, porém, não deve ser confundido com o "personagem" (forma qualificada/não qualificada), visto que um actante, tendo um certo papel narrativo (agressor, benfeitor, aliado, oponente, retribuidor etc.), pode ser ocupado por diferentes tipos de personagens, da mesma forma que um mesmo personagem pode desempenhar muitos papéis narrativos e, assim, ocupar o lugar de diferentes actantes no desenrolar de uma mesma história.

Os processos narrativos podem ser considerados como a semantização das açôes (uma ação correlacionada com outras açóes, motivada por uma intencionalidade) que determinarão a função narrativa. As funçôes narrativas, por sua vez, estão ligadas aos papéis narrativos dos actantes, que se determinam reciprocamente. Por exemplo, a ação "entrega de um embrulho", dependendo das açóes correlacionadas a ela, pode corresponder a um processo de agressão (bomba), de recompensa (presente) ou de enganação (pacote vazio).

Com relação às sequências, a lógica narrativa é composta por uma sucessão de acontecimentos ligados entre si por uma relação de solidariedade (princípio de coerência). A narrativa produzida, por sua vez, só terá sentido se estiver relacionada a um encadeamento de motivos dirigidos a um fim (princípio de intencionalidade). Essas ações ou esses acontecimentos reagrupam-se em sequências ordenadas segundo um princípio de encadeamento. Por fim, essa sucessão de acontecimentos coerente e motivada precisa 
ocorrer em um enquadramento espaço-temporal, segundo um princípio de localização (CHARAUDEAU, 2009, p. 166).

Os procedimentos de configuração da lógica narrativa podem estar ligados à motivação intencional, à cronologia, ao ritmo ou à localização espaço-temporal (op. cit., p. $175-183)$.

Os procedimentos ligados à motivação intencional consistem em atribuir ao agente de uma sequência narrativa uma intenção de agir (agente voluntário, consciente de seu projeto de fazer) ou uma ausência de intenção (agente não voluntário, que não tem projeto de fazer), podendo, nesse segundo caso, agir sob a influência de um outro agente (manipulação humana ou sobre-humana). Tais procedimentos incidem sobre os princípios de coerência e de intencionalidade.

Os procedimentos ligados à cronologia consistem em agir sobre a ordem e as relações de causalidade das sequências entre si. $\mathrm{O}$ encadeamento das sequências pode ser apresentado de maneira contínua, e essas sucederem-se de maneira progressiva (cronologia contínua em progressão) ou de maneira invertida (cronologia contínua em inversão); por outro lado, o encadeamento das sequências também pode ser apresentado de maneira descontínua, e essas serem interrompidas por uma descrição (cronologia descontínua em expectativa) ou pelo desenvolvimento de uma outra série de sequências (cronologia descontínua em alternância). Tais procedimentos obedecem ao princípio de encadeamento.

Os procedimentos ligados ao ritmo concernem ao que Genette (apud CHARAUDEAU, 2009, p. 181) chama de "variaçóes de ritmo de um texto narrativo". Segundo Charaudeau (op. cit., p. 181), a sucessão das sequências e ações na narrativa desenrola-se "ora rapidamente, ora lentamente, ora de forma condensada, ora de forma alongada" e tais variaçóes estão agrupadas em dois procedimentos: a condensação e a expansão. Tais procedimentos também obedecem ao princípio de encadeamento.

Já os procedimentos ligados à localização espaço-temporal concernem à situação no tempo (passado ou presente) e à localização no espaço (espaço fechado ou aberto, com deslocamento ou fixação), produzindo diferentes efeitos de narrativa. Tais procedimentos dependem do princípio de localização. 
Em textos que têm por finalidade contar, ainda estão presentes procedimentos que contribuem para uma construção ora objetiva, ora subjetiva de mundo, criando, assim, efeitos de realidade e de ficção. Os procedimentos de construção objetiva do mundo consistem em construir uma "visão de verdade sobre o mundo", qualificando os seres por meio de traços que possam ser verificados por seu interlocutor. Os procedimentos de construção subjetiva do mundo consistem em permitir ao sujeito falante descrever os seres do mundo e seus comportamentos por meio de sua própria visão, a qual não é necessariamente verificável; portanto, o universo assim construído está ligado ao imaginário pessoal do sujeito (CHARAUDEAU, 2009, p. 125). Tal imaginário pode tomar forma por meio: de uma intervenção pontual do narrador, quando este deixa transparecer seus sentimentos, afetos e opinióes; da construção de um mundo mitificado pelo narrador, num imaginário simbólico que pode estar ancorado em uma certa realidade ou fora desta, abrindo-se para o irracional.

A seguir, portanto, trataremos dos efeitos de realidade e ficção, pois a alternância entre esses dois efeitos é que constrói o "plano de fundo" (visão de mundo) em textos narrativos, como os quadrinhos.

\section{EFEITOS DE REALIDADE E FICÇÃo}

Mesmo sendo ficção, um texto é ancorado na realidade e conta com as experiências de mundo de autor e leitor para adquirir sentido. Nos quadrinhos, o efeito de realidade é criado quando são utilizadas imagens icônicas, próximas ao real, ou estereotipadas, para que o leitor reconheça nelas um mundo realista, por meio de seus saberes de crença e de conhecimento (imaginários sociodiscursivos), de modo a possibilitar a criação de imagens mentais que completem os espaços entre os quadros.

Os sistemas de representação icônica apresentam um caráter construído e são motivados pela semelhança com o dito "mundo natural" (o que confere certa identidade total ou parcial - entre os traços e as figuras do representado e do representante) e que, se 
esses são compreendidos por outras pessoas além daquelas que as fabricam, é porque existe um mínimo de convenção sociocultural, um caráter simbólico.

Com relação às imagens estereotipadas, Eisner aponta que

a arte dos quadrinhos lida com reproduçóes facilmente reconhecíveis da conduta humana. Seus desenhos são o reflexo no espelho, e dependem de experiências armazenadas na memória do leitor para que ele consiga visualizar ou processar rapidamente uma ideia. Isso torna necessária a simplificação de imagens transformando-as em símbolos que se repetem. Logo, estereótipos. Nos quadrinhos, os estereótipos são desenhados a partir de características físicas comumente aceitas [...]. Eles se tornam ícones e são usados como parte da linguagem na narrativa gráfica. (EISNER ,2005, p. 21-22).

Tal ideia está ligada à noção dos imaginários sociodiscursivos. "Estereótipo", nesse caso, não apresenta necessariamente um sentido negativo, ligado a um preconceito. Aqui, estereótipo pode ser definido como "uma ideia ou um personagem que é padronizado numa forma convencional, sem individualidade" (EISNER, 2005, p. 21), algo muito comum nos quadrinhos. Segundo Amossy e Pierrot, os estereótipos são

representaçôes cristalizadas, esquemas culturais preexistentes, através dos quais cada um filtra a realidade ao seu redor. Segundo Lippmann, estas imagens são indispensáveis para a vida em sociedade. Sem elas, o indivíduo estaria perdido no fluxo e refluxo da sensação pura; seria impossível a ele compreender o real, categorizá-lo ou atuar sobre ele. Como examinar cada ser, cada objeto em sua especificidade própria e em detalhes, sem vinculá-los a um tipo ou uma generalidade? [tradução nossa $]^{3}$ (AMOSSY E PIERROT, 2010, p. 32)

O uso de estereótipos nos quadrinhos visa facilitar a compreensão do leitor, ao apresentar padrões de fácil reconhecimento. No entanto, a identidade coletiva, com seu caráter homogeinizante, tende à formação de estereótipos negativos, com julgamentos que

\footnotetext{
${ }^{3}$ Texto original: Se trata de representaciones cristalizadas, esquemas culturales preexistentes, através de los cuales cada uno filtra la realidad de su entorno. Según Lippman, estas imágenes son indispensables para la vida en sociedad. Sin ellas, el individuo estaría sumido en el flujo y reflujo de la sensación pura; le sería imposible comprender lo real, categorizarlo o actuar sobre ello. ¿¿Cómo examinar cada ser, cada objeto en su especificidad propia y en detalle sin vincularlo a un tipo o una generalidad? (AMOSSY e PIERROT, 2010, p. 32)
} 
se consolidam e se generalizam, caricaturizando o outro. Charaudeau (2015, p. 19) afirma que o julgamento estereotipado é um fenômeno duplo: o julgamento que fazemos do outro diz algo sobre o outro, deformando-o e, reciprocamente, esse julgamento diz algo sobre nós mesmos. Os estereótipos podem formar preconceitos, por isso é preciso ficar atento a tais generalizaçôes para que não se perpetue uma visão negativa sobre determinado grupo.

Ao focalizar os quadrinhos, é possível ainda notar alguns recursos visuais construídos de modo subjetivo, mas que têm certa ancoragem no mundo objetivo, signos esses utilizados para "fazer o leitor imaginar". Como afirma Eisner (2005, p. 61), a mídia dos quadrinhos não tem som, música ou movimento e, dessa forma, utiliza recursos facilmente identificáveis pelo leitor, que participará da história, completando as lacunas e dando vida às cenas. Exemplos desses recursos são: o uso de balóes de fala, as onomatopeias, a representação de movimentos por meio das linhas cinéticas e da gestualidade.

Outro aspecto levantado por Eisner (2005, p. 54) com relação ao contrato leitor/narrador é a "luta para manter o interesse do leitor". Segundo ele, "depois que se consegue chamar a atenção do leitor, não se pode deixá-la escapar”. Nos mangás, se é a "arte" que atrai o leitor adolescente, inicialmente, o que realmente o prende é o enredo. Por esse motivo, a arte de contar histórias por meio de quadros será o foco da análise de corpus ao estudar como se constrói a lógica narrativa em três ediçóes da Turma da Mônica Jovem.

\section{CONSTRUINDO UMA SEQUÊNCIA DE EVENTOS}

O coração dos quadrinhos está no espaço entre um quadro e outro [...] onde a imaginação do leitor dá vida a imagens inertes. (MCCLOUD, 2006, p. 1)

De acordo com Barthes (1990, p. 31), desde o aparecimento do livro, a vinculação palavra-imagem é frequente. Dessa forma, escrita e imagem são "companheiras" no ato de contar histórias. Ciça Fittipaldi, reconhecida ilustradora de livros infanto-juvenis, descreve que 
[t]oda imagem tem alguma história para contar. Essa é a natureza narrativa da imagem. Suas figuraçóes e até mesmo formas abstratas abrem espaço para o pensamento elaborar, fabular, fantasiar. A menor presença formal num determinado espaço já é capaz de produzir fabulação e, portanto, narração. [...] Se ao olharmos uma imagem podemos perceber o acontecimento em ação, o estado representado, uma ou mais personagens "em devir", podemos imaginar também um (ou mais) "antes" e um (ou mais) "depois". E isso é uma narração. (FITTIPALDI,2008, p. 103).

O Modo Narrativo consiste em construir a sucessão das ações de uma história no tempo, com a finalidade de fazer um relato. Tal construção ocorre segundo uma lógica que vai constituir a trama da história - a lógica narrativa.

Para abordar elementos da lógica narrativa, neste momento, o estudo se centrará na edição no 63 do semimangá Turma da Mônica Jovem (SOUSA, 2013), que apresenta a história Dia das Bruxas e que traz uma construção narrativa bastante interessante. A edição contém uma narrativa maior composta por micronarrativas que inicialmente parecem independentes, mas interligam-se ao final da trama.

A revista A Turma da Mônica Jovem foi lançada pelos Estúdios Mauricio de Sousa em agosto de 2008 e é publicada mensalmente, geralmente no último fim de semana de cada mês, pela Panini Brasil. Em sua capa, é dito que é "aconselhável para maiores de 10 anos". A TMJ consiste em uma releitura dos personagens da turma tradicional em versão adolescente. Nela, portanto, os personagens aparecem "mais velhos" e a publicaçáo apresenta características que refletem questôes pertinentes ao "universo" a que comumente pertencem os indivíduos dessa faixa etária.

Além dos protagonistas (Mônica, Cebola, Cascão e Magali) e de antigos e novos personagens, personagens secundários e até mesmo vilóes da Turma da Mônica tradicional são frequentemente resgatados nas tramas criadas, dando origem a diferentes aventuras. A maioria das histórias acontece no Bairro do Limoeiro, onde mora a turma, e gira em torno de confusóes amorosas, vida escolar e familiar, valores e amizade, mas também há viagens espaciais, supervilôes, grandes invençôes tecnológicas, seres mitológicos ou de outro mundo e organizaçôes secretas. 
A publicação procura seguir o padrão dos mangás, com páginas em preto e branco, em encadernaçóes tipo brochura de $16 \times 21 \mathrm{~cm}$, capa colorida e histórias sequenciais - uma revista é continuação da outra. As revistas têm 130 páginas divididas em capítulos, com histórias de temas atuais, discutidos em meio às aventuras da turma. Cada edição apresenta, geralmente, uma aventura com início, meio e fim, sendo que algumas delas são mais longas e se estendem por duas ou três ediçôes (raramente por quatro ediçóes). A revista traz, em seu expediente, a relação dos profissionais responsáveis pela edição, ou seja, a equipe de produção (roteiro, layout do roteiro, desenho, capa, arte-final, letras, colorização, revisão, etc.) e adota, atualmente, um "rodízio" de roteiristas que elaboram tramas sob a aprovação prévia de Maurício de Sousa e Marina Takeda e Sousa, cada um com seu estilo próprio.

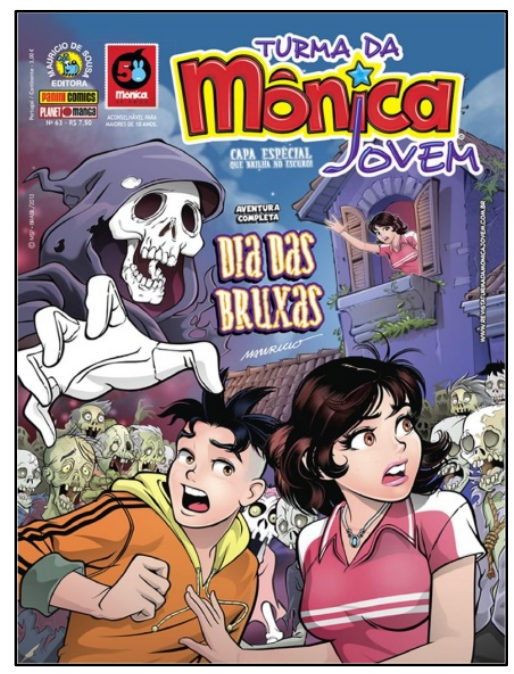

Figura 1: Capa da TMJ, ediçóes nº 63.

A edição no 63 foi publicada em outubro de 2013. A capa da edição (Fig. 1), Dia das Bruxas, é a primeira da série que brilha no escuro. A presença de uma caveira parecida com a "Dona Morte" e de zumbis, juntamente com o título, revela que se trata de uma história de terror. A presença da Mônica e do Cebola, ao centro, pressupóe que esses sejam os protagonistas dessa história (mas, na realidade, o são parcialmente, como será visto adiante). O fato de haver duas imagens da Mônica, uma delas na janela, como se estivesse pedindo ajuda, desperta a curiosidade do leitor; tal duplicidade só se explicará na leitura da revista. Essa capa pouco revela efetivamente do seu enredo, criando um efeito de suspense. 
A trama é complexa e a história possui um encadeamento em paralelismo, pois há diferentes sequências, cada uma regida por um actante-agente diferente, que se desenvolvem de maneira autônoma, sem que se liguem entre si por uma relação de causa e efeito, mas que se cruzam em um determinado momento e convergem para um mesmo final (CHARAUDEAU, 2009, p. 170). O próprio roteirista, Emerson Abreu, falou aos leitores sobre a revista em seu blog e explicou como desenvolveu a trama:

Primeiro, um pouco da história por trás da história... Quando fui convidado pra escrever mais um roteiro pro dia das Bruxas, eu já tinha uma história completa na minha cabeça, queria que fosse feita em duas ediçôes e tal... infelizmente, a edição de novembro já estava fechada e eu só teria uma edição pra contar minha história. Então, a única solução foi guardar esse meu roteiro pro ano que vem e criar uma história nova pra essa ediçáo. Eu lembrei então das velhas antologias de terror que saíam antigamente, com vários contos diferentes, cada um com um tema distinto (mais ou menos como os episódios especiais de Dia das Bruxas que os Simpsons fazem todos os anos). Decidi que a revista teria três histórias: uma de fantasma, uma sobre uma casa mal-assombrada e uma com zumbis. Assim, todos os elementos de filmes de horror estariam representados:

- A primeira história (a do fantasma) é mais pausada, mais cadenciada, pra criar um clima de tensão e suspense verdadeiro.

- A segunda (casa mal-assombrada) é mais voltada pro lado do bizarro, do inexplicável, do "além-da-imaginação".

- E, finalmente, a terceira (dos zumbis) é muita ação, terror e correria pra todo lado!

Mas, para deixar as coisas um pouco mais legais, decidi fazer todas as histórias interligadas. Várias coisas que aparecem numa história ficam sem explicação e você só vai entender depois que ler as outras histórias que mostram outros acontecimentos paralelos na visão de personagens diferentes. Por isso, recomendo que leiam essa ediçấo várias vezes, para entenderem muito bem tudo o que está acontecendo ali. $\mathrm{E}$, como não poderia deixar de ser, as três histórias juntas formam uma história completa porque entre cada história existe um interlúdio que liga todas elas num roteiro só, e todas as pontas soltas são amarradas depois da terceira história. Ficou massa! ${ }^{4}$

A história começa na tenda da Madame Creuzodete (Fig. 2). Madame Creuzodete do Abaeté é a vidente da Turma, que tem uma barraquinha no Bairro do Limoeiro. Ela foi criada por Emerson Abreu e aparece em várias revistas da Turma da Mônica e na edição no

\footnotetext{
${ }^{4}$ Disponível em: http://emersonabreu.blogspot.com.br/. Acesso em 03/10/2016.
} 
51 da Turma da Mônica Jovem (“Sombras do Passado”, parte 1), edição cuja história terá profunda relação com a trama analisada ( $\left.n^{\circ} 63\right)$.

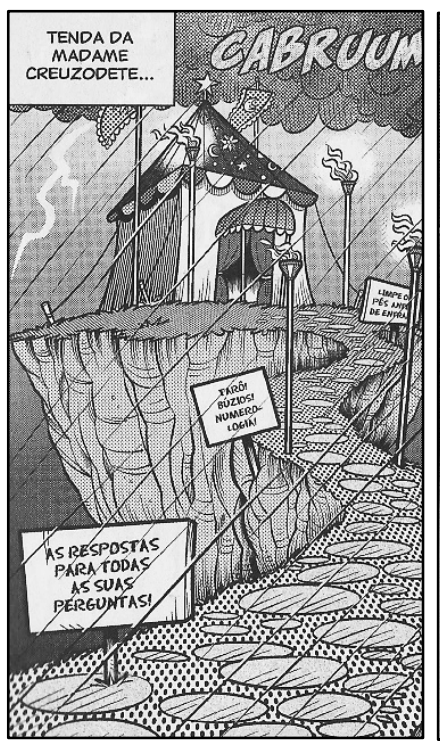

Figura 2: Localização. TMJ no 63, p. 5 .

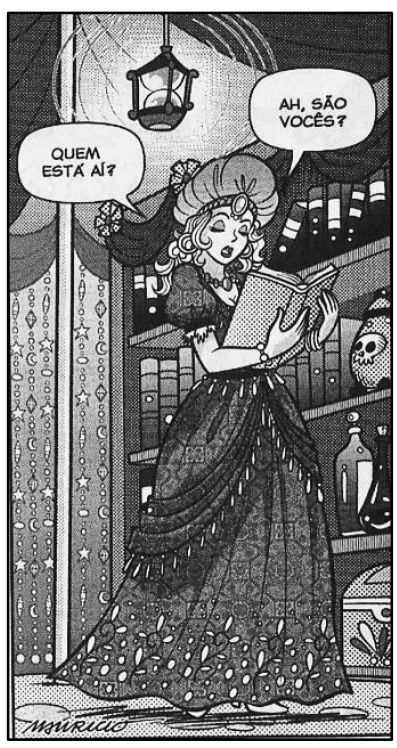

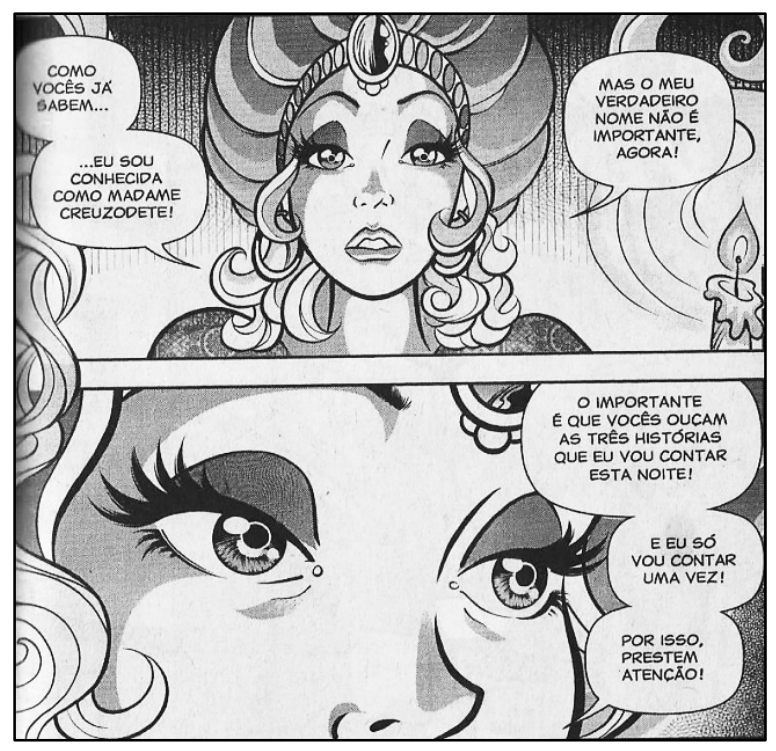

Figura 3: Narrador 1. TMJ no 63, p. 7.

Por ser uma figura ligada ao insólito na revista, é ela quem se coloca como narradora (EU enunciador) das histórias de terror (Fig. 3): "O importante é que vocês ouçam as três histórias que eu vou contar esta noite". Desse modo, teríamos o narrador principal (observador) - o mesmo de todas as revistas -, quando aparece a Madame Creuzodete, e ela seria a narradora (também em $3^{a}$ pessoa) das sequências paralelas. Em sua fala, pressupóe-se que ela se dirige aos leitores da revista (Fig. 2 e 3). No entanto, ao final (Fig. 4), percebe-se que os interlocutores do início da história, na verdade, são fantasmas, que vêm a sua tenda para ouvir histórias de terror no Dia das Bruxas. Isso proporciona um duplo sentido a "vocês", evidenciando o duplo sujeito destinatário (TUd): os fantasmas, no espaço interno ao texto, e o leitor, no espaço externo. 

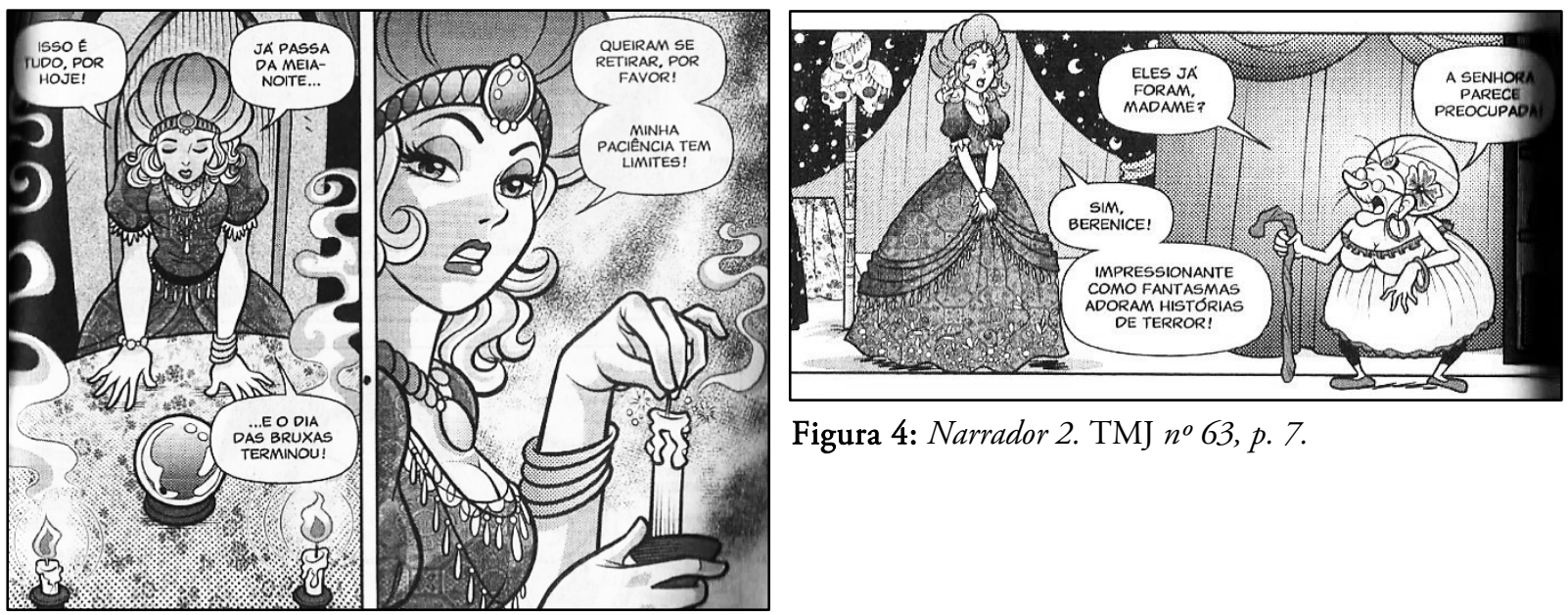

Figura 4: Narrador 2. TMJ $n^{\circ} 63, p .7$.

A Madame Creuzodete passa, então, a narrar as três histórias, olhando em sua bola de cristal. As três sequências, conforme foi mencionado, desenvolvem-se de maneira independente, mas estão interligadas entre si. Além da introdução e da conclusão feitas pela Madame, há entre as sequências um interlúdio, no qual a narradora faz a conexão entre as partes, formando uma única história, conforme explicou o roteirista.

A primeira história ocorre no Colégio do Limoeiro. A turma prepara uma festa do Dia das Bruxas, organizada pela Denise, no saláo da escola. Cebola diz que vai à casa do Franja para ajudar a terminar as fantasias dele e da Mônica. Chega a Magali fantasiada de bruxa, com uma capa, um cajado e um medalhão. Logo depois chegam a Denise, a Sofia e, por último, o Cascão. No meio da conversa, as meninas ouvem um trovão (Fig. 5), o que confere um ar de mistério à narrativa e muda seu "clima", pois Magali começa a ter estranhas sensaçóes. Denise, então, resolve dispensar o pessoal que está trabalhando para se arrumar. Mônica vai para casa do Franja vestir sua fantasia. Ficam no saláo da escola a Denise, a Magali, a Sofia e o Cascão. Um fantasma toma o corpo de Denise e ataca Sofia. O fantasma, no corpo de Sofia, joga Cascão contra a janela. Magali tenta ajudá-lo, mas o fantasma agora está no corpo dele e passa para o corpo dela (Fig. 6). Acaba, assim, a primeira narrativa. 


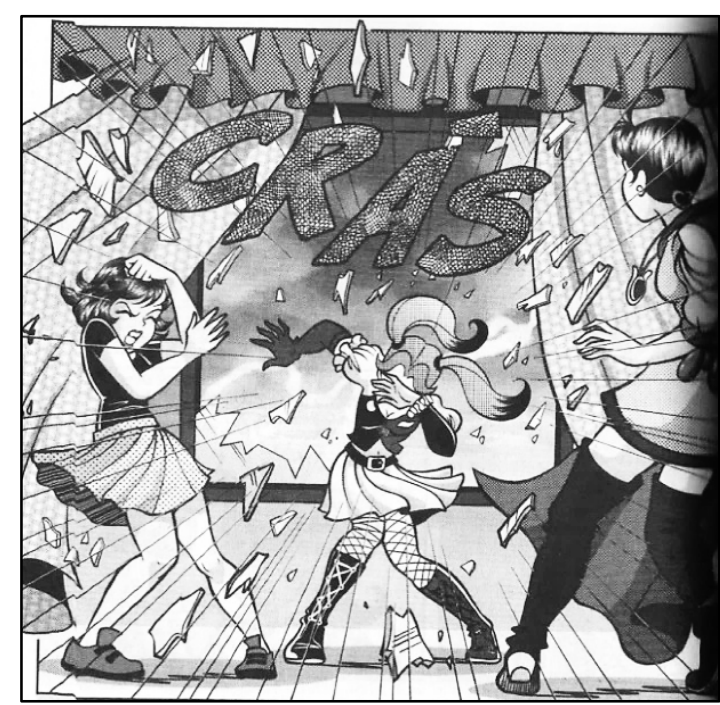

Figura 5: Micronarrativa 1A. TMJ no 63, p. 26.

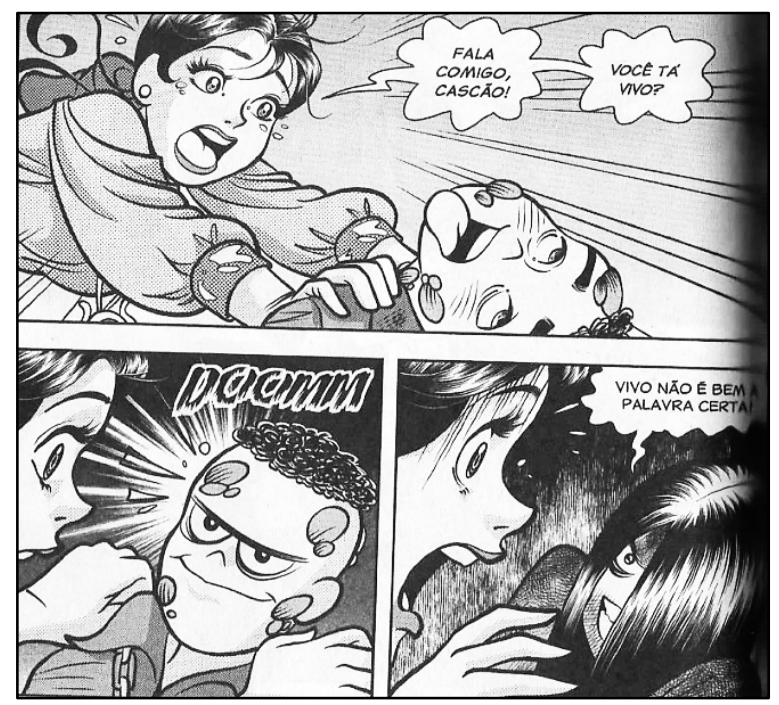

Figura 6: Micronarrativa 1B. TMJ $n^{\circ} 63, p .44$.

A segunda é a mais complexa de todas as narrativas. Cebola está do lado de fora de um casarão abandonado esperando a Mônica, após receber uma ligação dela. Decide pular o muro para encontrá-la e, do outro lado, vê a Mônica na janela do segundo andar da casa, pedindo ajuda, como na capa da revista (Fig. 7). Cebola volta para buscar ajuda, encontra a Mônica do lado de fora da casa e não entende nada. Ela diz que estava indo para a casa do Franja encontrá-lo. Nessa hora, Cebola se lembra da "outra Mônica”. Eles decidem entrar na casa para resolver o mistério e ajudar a menina. Ao abrirem a porta, saem dois pássaroscucos desesperados (Fig. 8).

Figura 7: Micronarrativa 2A. TMJ $n^{\circ} 63$, p. 51.

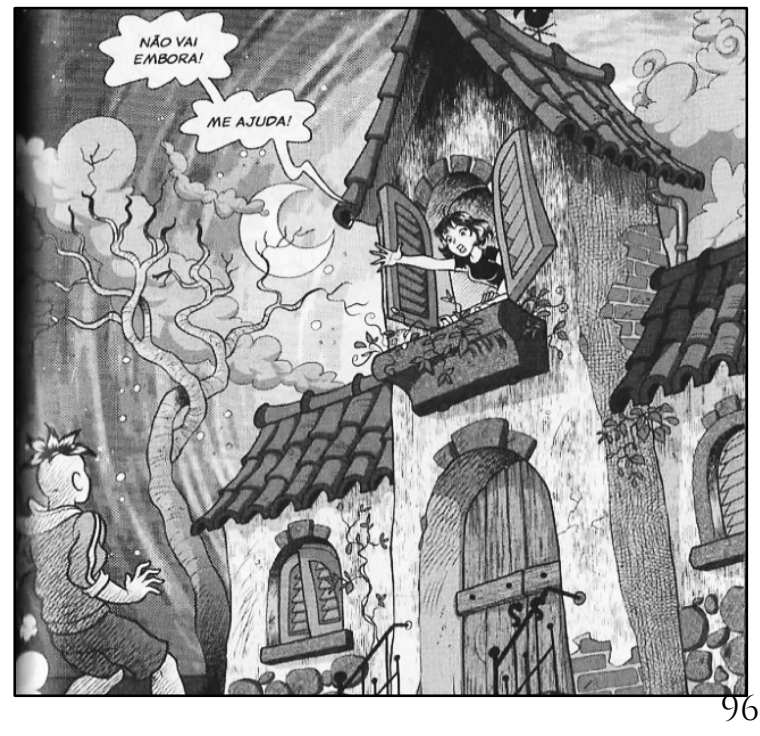

Figura 8: Micronarrativa 2B. TMJ $n^{\circ} 63, p .60$.

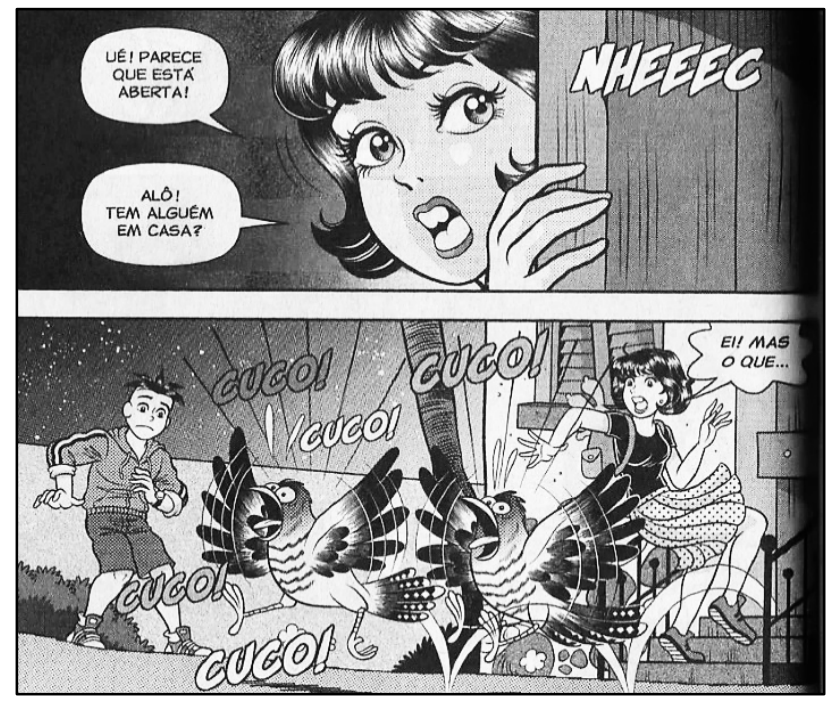


Após uma sequência de eventos repetidos e cruzados dentro da casa, Mônica encontra um livro. É o diário do dono da casa, no qual estava escrito que o lugar estava sob uma "magia temporal" e que, se alguém ficasse muito tempo lá, se transformaria em um pássaro cuco. Mônica se dá conta de que eles já estavam presos pelo fenômeno. Ao tentarem fugir, Mônica e Cebola transformam-se em pássaros-cucos e encontram a si mesmos entrando na casa. Termina a segunda sequência.

A terceira narrativa ocorre durante a festa do Dia das Bruxas. Todos estáo dançando e Magali está com um olhar sombrio. De repente, aparecem Mônica e Cebola em forma de pássaro. Eles se aproximam do medalhão da Magali e voltam ao normal. Nisso, Magali flutua, faz a Mônica flutuar, agarra em seu pescoço e diz que está se vingando mais uma vez (Fig. 9). Ao ver seu "olhar de desprezo", Mônica se dá conta de que se trata de Penha, sua inimiga. Penha diz que, por culpa deles, ela estava presa num estado de morte em vida, mas que, naquele dia, alguma coisa aconteceu e ela conseguiu separar seu espírito do corpo. Nesse instante, Magali toma o controle de seu corpo novamente e ordena que Penha saia da mente dela, mas quando eles olham ao redor, Penha tinha possuído todos da festa e transformou-os em zumbis. Magali, com o poder do medalhão, faz com que tudo volte ao normal, manda Penha para o lugar de onde veio e pede explicaçóes à Sofia. Sofia conta que o corpo da Penha estava em coma há um ano em um hospital, pois, quando tentou empurrar a Mônica de um penhasco, ela bateu a cabeça. Eles vão visitá-la (Fig. 10). Magali, para ajudar, cria uma magia para que o medalhão cure o seu corpo e mantenha seu espírito dentro dele. Sofia sugere que eles voltem para festa. Encerra-se a terceira narrativa.

Figura 9: Micronarrativa 3A. TMJ no 63, p. 96.

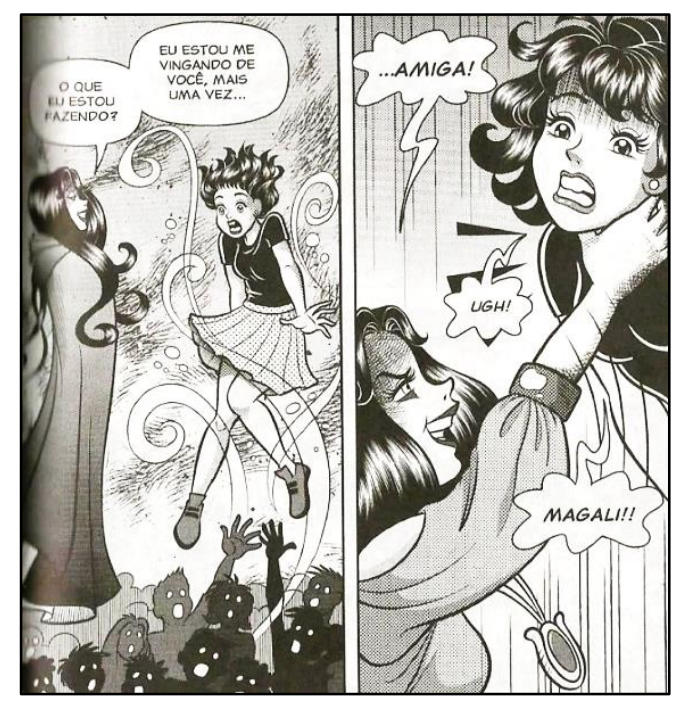

Figura 10: Micronarrativa 3B. TMJ no 63, p. 119.

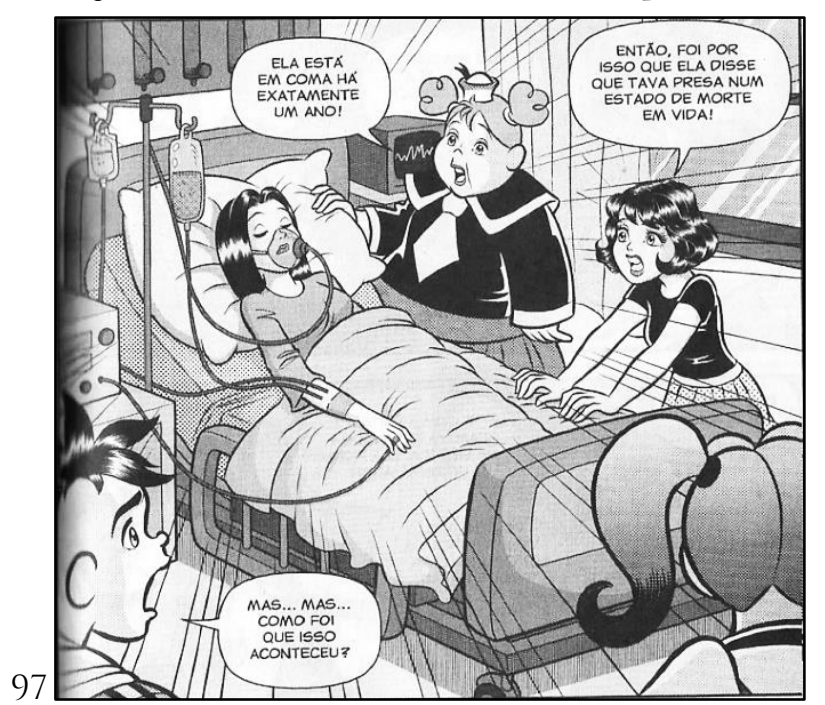


Madame Creuzodete reaparece e diz que é o fim e, na verdade, também o início. Já passava da meia-noite e o dia das bruxas tinha terminado; no entanto, ela revela que as crianças não sabiam que o medalhão não era mágico, era apenas um enfeite, e que a fonte de todo aquele poder era a própria Magali.

Os capítulos de Dia das Bruxas são divididos da seguinte maneira (princípio de encadeamento): "A noite da vingança” (p. 8); "Morte em vida” (p. 23); "A casa fora do tempo" (p. 51); “Terror em reverso” (p. 66); "Baladinha monstra” (p. 90); “O despertar da bruxa” (p. 104). A história ainda conta com um prelúdio (p. 5-7) e um poslúdio (p. 123124), nos quais a Madame Creuzodete introduz e encerra as histórias.

Conforme foi mencionado, há uma narrativa principal, cujo principal actante é Madame Creuzodete. Sua abertura é marcada pela chegada dos fantasmas para ouvirem a história que a vidente tem para contar, e seu fechamento é quando chega a meia-noite e eles vão embora. Quanto ao princípio de intencionalidade, a Madame Creuzodete conduz o projeto de fazer, que é contar uma história de terror no Dia das Bruxas.

A primeira narrativa refere-se aos dois primeiros capítulos: "A noite da vingança" e "Morte em vida". Esta tem como abertura a chegada da Magali ao saláo da escola, onde todos preparavam a festa, e o fechamento se dá quando a festa está prestes a iniciar (a Denise diz que vai ligar o som antes que "o povo comece a chegar"). Quanto ao princípio de intencionalidade, a Denise conduz o projeto de fazer principal, que é preparar uma festa de Dia das Bruxas ajudada por seus amigos (cada um prepara sua fantasia e ajuda na arrumação de alguma forma), só que, no meio dos preparativos, coisas estranhas acontecem.

A segunda narrativa refere-se, principalmente, ao terceiro e quarto capítulos: "A casa fora do tempo" e "Terror em reverso", sendo que sua abertura ocorre logo no primeiro capítulo, no momento em que o Cebola vai para a casa do Franja ajudar a terminar as fantasias; o fechamento é no quinto capítulo, quando Cebola e Mônica chegam à festa como pássaros e voltam ao normal quando chegam perto da Magali. Quanto ao princípio de intencionalidade, primeiramente, eles querem que suas fantasias fiquem prontas a fim de se arrumarem para a festa (mas não têm êxito por conta dos eventos ocorridos); depois, desejam ajudar a "outra Mônica” (e também fracassam, pois não existia “outra Mônica”); 
por último, querem se livrar da casa e do seu feitiço (nisso eles tiveram êxito, pois conseguiram fugir atraídos pela luz da Magali e, por meio do poder que emanava dela, voltaram ao normal).

A terceira narrativa refere-se aos dois últimos capítulos: "Baladinha monstra" e "O despertar da bruxa". Esta tem como abertura o início da festa, com todos dançando, e o fechamento se dá quando, após visitarem a Penha no hospital, decidem voltar para a festa. Quanto ao princípio de intencionalidade, o fantasma da Penha conduz o projeto de fazer principal, que é se vingar da turma e acabar com a Mônica. Só que ela fracassa, pois é impedida pela Magali, que a manda de volta para seu próprio corpo, que está em um hospital.

Quanto aos actantes, Penha é um agente agressor e o faz de forma voluntária; Magali é um agente benfeitor, pois salva os amigos; Denise é agente aliado, pois ajuda a Magali a "acessar" o seu poder; Mônica sofre a ação e é vítima das ações da Penha, além de beneficiária das ações da Magali. Cebola é aliado. Cascão e Sofia são aliados, mas, quando são possuídos pela Penha, tornam-se oponentes.

Quanto ao princípio de localizaçâo, em relação ao espaço, a narrativa principal acontece na tenda da Madame Creuzodete (espaço fechado); a primeira narrativa, no Colégio do Limoeiro, mais especificamente no salão, no porão (espaços fechados) e no pátio (espaço aberto); a segunda narrativa em uma casa abandonada, que é assombrada (espaço fechado); a terceira narrativa ocorre novamente na escola e no hospital (espaços fechados). Com relação ao tempo, a história acontece no Dias das Bruxas (31 de outubro); a primeira narrativa ocorre antes da festa e a terceira durante a festa; a segunda narrativa atravessa as outras duas, iniciando-se um pouco antes da festa começar e terminando logo após seu início. Tem-se um efeito de atualidade, pois é como se as açóes ocorressem no momento da leitura. No entanto, como as histórias são contadas pela Madame Creuzodete, há também um efeito de ficção autobiográfica (cf. CHARAUDEAU, 2009, p. 182).

A história apresenta uma cronologia descontínua em alternância, pois "uma sequência narrativa, de maior ou menor importância, é interrompida em seu desenrolar por uma 
outra sequência narrativa que se desenvolve paralelamente à precedente com um agente diferente do anterior". (CHARAUDEAU, 2009, p. 180).

Quanto ao ritmo, conforme explicou o próprio roteirista, a primeira narrativa (a do fantasma) é mais lenta para "criar um clima de tensão e suspense". Na segunda (a da casa mal-assombrada), o ritmo varia: em certos momentos é mais lento, para criar um ar de mistério e um efeito de suspense, e, em outros, como no final, quando querem fugir ao descobrir que a casa está sob o efeito de uma magia, é mais acelerado. A terceira (dos zumbis) é mais acelerada, pois há bastante "ação, terror e correria”.

Desse modo, num plano mais geral, a lógica narrativa da edição no 63 poderia ser resumida da seguinte maneira:

\begin{tabular}{|c|c|c|}
\hline \multicolumn{3}{|c|}{ ORGANIZAÇĀO DA LÓGICA NARRATIVA NA EDIÇÓES No 63 DA TMJ } \\
\hline & Tópicos Revista & Dia das Bruxas (no 63) \\
\hline \multirow{2}{*}{ 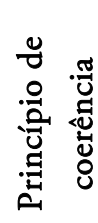 } & Abertura & $\begin{array}{c}\text { A chegada dos fantasmas à tenda da Madame Creuzodete para ouvirem a história que a } \\
\text { vidente tem para contar }\end{array}$ \\
\hline & Fechamento & O relógio passa da meia-noite e os fantasmas vão embora \\
\hline \multirow{4}{*}{ 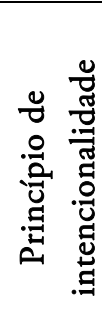 } & Actante principal & Madame Creuzodete \\
\hline & 岕 & Fantasmas querem ouvir histórias de terror no Dia das Bruxas \\
\hline & Busca & Madame Creuzodete precisa contar uma história de terror para os fantasmas \\
\hline & Resultado & Êxito, pois ela conta a história e os fantasmas vão embora \\
\hline \multirow{2}{*}{ 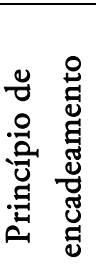 } & $\begin{array}{l}\text { Tipo de } \\
\text { encadeamento }\end{array}$ & $\begin{array}{c}\text { Em paralelismo } \\
\text { (Há diferentes sequências que se desenvolvem de maneira autônoma, mas que se } \\
\text { cruzam) }\end{array}$ \\
\hline & Cronologia & Cronologia descontínua em alternância \\
\hline \multirow{2}{*}{ 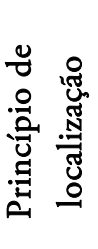 } & $\begin{array}{l}\text { Situaçáo no } \\
\text { tempo }\end{array}$ & $\begin{array}{l}\text { A narrativa ocorre no Dias das Bruxas, } 31 \text { de outubro (efeito de atualidade) e três } \\
\text { histórias são contadas (efeito de ficção de autobiografia) }\end{array}$ \\
\hline & $\begin{array}{l}\text { Localizaçáo no } \\
\text { espaço }\end{array}$ & $\begin{array}{l}\text { O espaço principal é a tenda da Madame Creuzodete (espaço fechado, sem } \\
\text { deslocamentos) }\end{array}$ \\
\hline
\end{tabular}

Quadro 1: A organização da lógica narrativa em três ediçóes da TMJ 
Por outro lado, a lógica narrativa das três micro sequências da edição 63, Dia das Bruxas, poderia ser representada por meio do seguinte quadro:

\begin{tabular}{|c|c|c|c|}
\hline 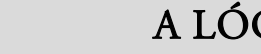 & A NARRATIVA & EQUÊN & 063 \\
\hline Seq & $\begin{array}{l}\text { 1ª sequência: } \\
\text { Fantasma }\end{array}$ & $\begin{array}{c}\text { 2a sequência: } \\
\text { Casa mal assombrada }\end{array}$ & $\begin{array}{c}\text { 3a sequência: }^{\text {Zumbis }} \\
\text { Zumb }\end{array}$ \\
\hline Capítulos & $\begin{array}{l}\text { “A noite da vingança” e } \\
\text { "Morte em vida" (1 e } 2 \text { ) }\end{array}$ & $\begin{array}{l}\text { “A casa fora do tempo" e } \\
\text { “Terror em reverso" (3 e 4) }\end{array}$ & $\begin{array}{l}\text { "Baladinha monstra" e "O } \\
\text { despertar da bruxa" (5 e 6) }\end{array}$ \\
\hline Abertura & $\begin{array}{c}\text { A chegada da Magali ao salão } \\
\text { da escola, onde todos } \\
\text { preparavam a festa. }\end{array}$ & $\begin{array}{l}\text { Ainda no } 1^{\circ} \text { capítulo, no } \\
\text { momento em que o Cebola vai } \\
\text { para a casa do Franja ajudar a } \\
\text { terminar as fantasias. }\end{array}$ & $\begin{array}{l}\text { O início da festa, com todos } \\
\text { dançando }\end{array}$ \\
\hline Fechamento & $\begin{array}{l}\text { O momento em que a festa } \\
\text { está prestes a iniciar. }\end{array}$ & $\begin{array}{l}\text { No } 5^{\circ} \text { capítulo, quando Cebola } \\
\text { e Mônica chegam à festa como } \\
\text { pássaros e voltam ao normal ao } \\
\text { chegarem perto da Magali. }\end{array}$ & $\begin{array}{l}\text { Quando, após visitarem a } \\
\text { Penha no hospital, decidem } \\
\text { voltar para a festa. }\end{array}$ \\
\hline $\begin{array}{l}\text { Actantes } \\
\text { principais }\end{array}$ & Denise & Mônica e Cebola & O fantasma da Penha \\
\hline $\begin{array}{l}\text { Projeto de } \\
\text { fazer e } \\
\text { resultado }\end{array}$ & $\begin{array}{l}\text { Há uma festa de Dia das } \\
\text { Bruxas na escola que precisa } \\
\text { ser preparada para acontecer } \\
\text { Tem êxito, pois apesar de } \\
\text { coisas estranhas acontecerem } \\
\text { no meio dos preparativos, a } \\
\text { festa é realizada. }\end{array}$ & $\begin{array}{l}\text { 2) Eles querem ajudar a “outra } \\
\text { Mônica” (também fracassam, } \\
\text { pois não existia “outra } \\
\text { Mônica”); } \\
\text { 3) Eles querem se livrar da casa } \\
\text { e do seu feitiço (nisso eles } \\
\text { tiveram êxito, pois } \\
\text { conseguiram fugir e, por meio } \\
\text { do poder que emanava da } \\
\text { Magali, voltaram ao normal). }\end{array}$ & $\begin{array}{l}\text { A Penha fracassa, pois é } \\
\text { impedida pela Magali, que a } \\
\text { manda de volta para seu } \\
\text { próprio corpo, que está em } \\
\text { um hospital. }\end{array}$ \\
\hline
\end{tabular}




\begin{tabular}{|c|c|c|c|}
\hline $\begin{array}{l}\text { Localização } \\
\text { espaço- } \\
\text { temporal }\end{array}$ & $\begin{array}{l}\text { O Colégio do Limoeiro, mais } \\
\text { especificamente no salão, no } \\
\text { porão (espaços fechados) e no } \\
\text { pátio (espaço aberto), antes da } \\
\text { festa }\end{array}$ & $\begin{array}{l}\text { Uma casa abandonada que é } \\
\text { assombrada (espaço fechado); } \\
\text { começa um pouco antes da } \\
\text { festa começar e termina logo } \\
\text { no início da festa }\end{array}$ & $\begin{array}{c}\text { Na escola e no hospital } \\
\text { (espaços fechados), durante a } \\
\text { festa }\end{array}$ \\
\hline
\end{tabular}

Quadro 2: A lógica narrativa nas micro sequências da edição 63

No episódio Dia das Bruxas (edição no 63), ainda é possível observar que a alternância entre efeito de ficção e efeito de realidade é bastante aparente. Ancorando-se no cotidiano da turma, é criado um mundo mitificado que mistura o insólito à vida dos personagens. A história não se passa no espaço, em alguma realidade paralela, no futuro ou no mundo virtual, como ocorre muitas vezes, mas na própria escola em que a turma frequenta, durante uma festa que estavam organizando. O elemento que desencadeia essa "mistura" é o fato de a narrativa acontecer no Dia das Bruxas.

Com relação ao efeito de realidade, temos o frame de uma festa de Dia das Bruxas organizada pelos alunos, o que evoca todo um imaginário do leitor a respeito de situaçóes ligadas a esse evento e faz com que ele reconheça nessas situaçóes um mundo realista: alunos ajudando na arrumação da festa; uso de fantasias; cenário com caveiras, abóboras, velas, caldeirão etc.; hits de sucesso na hora da dança (na revista, eles dançam ao som de "Show das Modernosas", clara paródia à música "Show das Poderosas", da cantora Anitta, sucesso em 2013, ano de publicação da revista). Outro elemento é a linguagem utilizada pelos personagens, com gírias bastante utilizadas pela faixa etária (exemplos: "Essa festa vai ser babado, confusão e gritaria”; "Tô zoando contigo, amiga!"; “A festa tá bombando! Tá curtindo, amiga?"), que ajudam a remontar ao universo adolescente.

No entanto, dentro desse contexto, é criado um mundo mitificado, ligado ao insólito e ao terror, com elementos que povoam o imaginário simbólico das pessoas com relação ao Dia das Bruxas: casas mal assombradas, fantasmas, zumbis, bruxas e experiências com o sobrenatural. Para tornar tudo ainda mais fora do comum e criar a atmosfera pretendida, o narrador principal coloca a Madame Creuzodete como contadora das histórias. 
A figura desse narrador principal, nos quadrinhos, apesar de ser às vezes imperceptível, é de extrema importância. O narrador não é o autor, mas "uma entidade de ficção, isto é, uma criação linguística do autor, e, portanto, só existe no texto" (GANCHO, 2016, p. 30). Muitos podem pensar que as histórias em quadrinhos não teriam um narrador, já que as personagens "ganham vida" e as cenas se desenrolam durante a leitura. No entanto, essa presença existe; é ele quem controla a narrativa. Assim, além de aparecer nas legendas, o narrador está presente na distribuição dos personagens, na manipulação da leitura por meio dos jogos de enquadramento (como se fosse a câmera do cinema), na marcação de tempo e ritmo (distribuição de açôes em quadros; quanto mais quadros para descrever uma ação, mais se tem a ideia de lentidão), ou seja, nas escolhas feitas ao se contar graficamente a história.

No caso da Turma da Mônica Jovem, a revista tenta criar a sensação de que o narrador principal das histórias é o próprio Maurício de Sousa, criador da turma. Na sessão "Fala Maurício", o narrador estabelece contato com o leitor destinatário e é como se ele soubesse tudo sobre o enredo, sobre as personagens e sobre os locais, enfim, como se ele mesmo tivesse conduzido a história; nessa sessão, ele ainda destaca os elementos que ele não quer que passem despercebidos e sobre os quais ele quer que o leitor reflita.

Enfim, as histórias de terror são outro tema apreciado pelo público adolescente. $\mathrm{Na}$ sessão Fala Maurício, o narrador implícito comenta sobre isso e tenta dar explicações a esse interesse:

Quem já não sentiu um arrepio de medo, um eriçar dos cabelos da nuca numa situação de insegurança, de pavor? Quem não derramou uma boa dose de adrenalina pelo corpo num momento de forte susto? O corpo reage. O espírito manda. [...]. Náo à toa os chamados filmes de medo são os mais procurados nas locadoras. Principalmente pelos adolescentes, pelos jovens. Mas por que esta busca pelo susto? Por que vamos buscar emoçôes em situações simuladas? Talvez seja a nostalgia remanescente dos tempos em que situaçóes de medo, de pavor, realmente ameaçavam o gênero humano, de quando ainda estávamos escondidos em cavernas, encurralados por feras ou inimigos mortais. Sobrou, para agora, o exercício de reviver os velhos pavores... sem perigo real, buscando nos filmes, nos efeitos especiais fantásticos, um pouco das lembranças ancestrais, para pensarmos um pouco no que faríamos para escapar ou nos defendermos. Daí as brincadeiras, jogos e festas de vampiros, de assombração, de lobisomens. Geralmente mais buscados pelos mais novos 
e que vão sendo deixados pelos mais velhos. [...]. (Trecho de "Fala, Maurício", $T M J$ no 63, p. 125)

Esse narrador, portanto, descreve esse momento como uma "fuga da realidade" para extravasar emoçóes. Ele complementa ao perguntar sobre quem gostaria de brincar com uma situação mais próxima da sua realidade. Segundo ele, principalmente os adolescentes e jovens buscam, em situaçôes simuladas, viver "um outro mundo", sentir diferentes emoçôes, o que, conforme já foi mencionado, é a especialidade dos mangás.

\section{ENFIM, A ARTE-FINAL}

O presente trabalho, sob o olhar da Teoria Semiolinguística de Análise do Discurso (CHARAUDEAU, 1992; 2009), procurou analisar a lógica narrativa presente na edição 63 do "semimangá" Turma da Mônica Jovem, de Maurício de Sousa, produzida por meio da relação palavra-imagem, focalizando a construção do modo narrativo e os efeitos de realidade e ficção criados.

As histórias em quadrinhos possuem uma linguagem muito peculiar. A leitura de textos mistos como os quadrinhos, nos quais palavra e imagem se inter-relacionam na arte de contar histórias, exige uma leitura diferente daquela realizada em textos puramente verbais. Nas narrativas verbais, o narrador é quem conduz o leitor que projetará representaçóes mentais daquilo que lê de acordo com a lembrança de experiências armazenadas na memória. Tal projeção mental refletirá, portanto, o conhecimento de mundo do leitor, seja acionada pela experiência empírica, por representaçôes verbais ou por imagens visuais. Nas narrativas verbo-visuais, por sua vez, as imagens são fornecidas visualmente pelo narrador, que parte de uma construção objetiva de mundo para realizar uma construção subjetiva dele. Espera-se daí que o leitor compreenda, por meio das representações estáticas, muitas vezes estereotipadas, aspectos como tempo decorrido, espaço, movimento, som, emoçóes e situações implícitas. É no espaço entre os quadros que "a imaginação humana capta duas imagens distintas e transforma em uma única ideia”, dando "vida" e sequência à história (MCCLOUD, 1995, p. 66). 
As histórias em quadrinhos constituem gêneros tipicamente narrativos e, por isso, o entendimento da construção da lógica narrativa se faz importante, pois é por meio dela que se organiza a trama da história, com a sucessão das açôes no tempo, formando um todo coerente. Como o sentido é apreendido na relação palavra-imagem, saber ler os elementos que compóem os quadrinhos torna-se essencial. Os quadros fornecem imagens estáticas, mas a imaginação do leitor "dá vida" a tais imagens, formando uma sequência lógica e atribuindo sentido ao que se lê/vê.

Com relação à publicação, por suas peculiaridades, carregando um pouco do gênero japonês, do estilo e da filosofia traçados na trajetória de 50 anos de Turma da Mônica, o autor chama carinhosamente a publicação de "mangá caboclo" (LUYTEN, 2012, p. 8) e até mesmo de "semimangá" 5 . Todas as características apresentadas até aqui mostram como o mangá pode ser envolvente e tem grande potencial para atrair o público jovem. O senso de participação, a fluidez da leitura e a dinamicidade dos quadros são fatores essenciais para tal sucesso. Ao misturar subjetividade e objetividade, é possível provocar determinadas sensaçóes no leitor, fazendo com que este se sinta parte da história e tenha momentos de fruição, nos quais pode viver um mundo diferente do seu - seja realista ou imaginário - e experienciar diferentes emoçôes.

\footnotetext{
${ }^{5}$ Entrevista à revista IstoÉ, no 2190, publicado em 21/10/2011. Disponível em: http://www.istoe.com.br/ assuntos/entrevista/detalhe/172219 A+INFANCIA+NAO+ESTA+MAIS+CURTA+. Acesso em 12/06/2012.
} 


\section{REFERÊNCIAS}

AMOSSY, Ruth; PIERROT, Anne Herschberg. Estereotipos y clichés. 1 ed. 4 reimp. Buenos Aires: Eudeba, 2010.

BAKHTIN, Mikhail. Estética da Criação Verbal. Tradução de Maria Ermantina Galvão G. Pereira. 2 ed. São Paulo: Martins Fontes, 1994.

BARTHES, Roland. O óbvio e o obtuso: ensaios críticos III. Trad. Lea Novaes. Rio de Janeiro: Nova fronteira, 1990.

CHARAUDEAU, Patrick. Grammaire du sens et de l'expression. Paris, Hachette, 1992.

CHARAUDEAU, Patrick. Linguagem e discurso: modos de organização. $1^{\mathrm{a}}$ ed., $1^{\mathrm{a}}$ reimpressão. São Paulo: Contexto, 2009.

CHARAUDEAU, Patrick. Identidade linguística, identidade cultural: uma relação paradoxal. In: LARA, G. P.; LIMBERTI, R. P. (org.). Discurso e (Des)igualdade social. São Paulo: Contexto, 2015. p. 13-29.

EISNER, Will. Narrativas Gráficas. São Paulo: Devir, 2005.

FITTIPALDI, Ciça. O que é uma imagem narrativa. In: OLIVEIRA, Ieda (org.). O que é qualidade em ilustraçâo no livro infantil e juvenil: com a palavra o ilustrador. São Paulo: DCL, 2008.

GANCHO, Cândida Vilares. Como analisar narrativas. 9. ed. São Paulo: Ática, 2006.

LUYTEN, Sônia Bide. Mangá: o poder dos quadrinhos japoneses. 3 ed. São Paulo: Hedra, 2012.

SANTAELLA, L. Matrizes da Linguagem do Pensamento: Sonora, Visual, Verbal. 1 ed. São Paulo: Iluminuras, 2005.

SOUSA, Maurício. Turma da Mônica Jovem, no 63. "Dia das Bruxas". São Paulo: Panini Brasil, outubro de 2013. 